\title{
STUDENT'S PERCEPTION TOWARDS FINANCIAL MANAGEMENT IN ENGLISH INSTITUTION COURSE
}

\author{
Riatul Farohah ${ }^{1}$, Viny Setiani ${ }^{2}$, Iman Santoso $^{3}$ \\ IKIP Siliwangi \\ ${ }^{1}$ riatulfarohah@gmail.com, ${ }^{2}$ vikunikusatya@ gmail.com, ${ }^{3}$ imansantoso515@gmail.com
}

\begin{abstract}
Perspective in education has a role to evaluate the effectiveness of the teaching-learning process. This research was conducted to know the students' perspective about teaching and learning process of Financial Management in English Institution course whether it effective or not. A sampling method was used to select the representative sample. To collect the data, this research used the questionnaire which showed the students' perception of Financial Management Course. The result of the study indicated that Financial Management in English Institution course has the positive perspective from students, this is evidenced by the high positive percentage of each statement. According to the result, Financial Management in English Institution course is acceptable by the student, 68.35\% students gave the positive perspective to this course even though the material has considerable differences with English education materials, it means that teaching and learning process of Financial Management course was effective. But $31.65 \%$ students gave negative perspective, it means that this course need improvement in many aspects and students can get the advantages of this course. Because financial management is also required in managing the finances of an institution including English education institutions, therefore students of English education also need to study this course.
\end{abstract}

Keywords: Students' perception, Financial Management course

\section{INTRODUCTION}

Education is growing nowadays, and it is marked by the changing the use of curriculum, it is adjusted to the needs and development of education. When curriculum changes it also affect the content, objectives and learning outcomes. And this is one reason for the existence of Financial Management course in English institution which was studied by the students of English education because it adapts to the needs and development of students' skills in managing the finances of an educational institution, especially English education institutions. The giving of this course is expected to give the students about the understanding of how to manage the finance in an institution in this case, the educational institution. So in the future, English education students are not only skilled in the context of English language and teaching but also able to manage the finances in educational institutions.

Financial Management is very important because it is related to funds of the company, especially educational institutions. Financial management guides to finance manager to make the optimum position of funds. With the study of financial management, we can protect the money. In financial management, we deeply study our balance sheet and all sensitive facts should be watched which can endanger our business into a loss. According to (Howard, 2016) presenting students with a hands-on learning activity can help them construct better mental models of the activity and encourages learning and inquiry. However, the financial material can be ineffective if presented in the classroom using slides. With learning about this course expected students can analysis finance management, understanding how to manage the finance especially in educational institutions. According to (Pamungkas, Kaswan, Sudiyono, \& Hariyudin, 2016) Financial management is about : analyzing financial situations, making 
financial decisions, setting financial objectives, formulating financial plans to attain those objectives, and providing effective systems of financial control to ensure plans progress towards the set objectives. These activities can present in the form of a financial management process which will be explained shortly.

The existence of this course reaps a variety of different perspectives from students both positive or negative perceptive because the material of this course focuses on financial management which is identical to the calculation which is generally rare studied by students who are majoring in languages, in this case, English education student. The differences between perspectives are due to the ability and the different characteristics of the student. The student's perspective can be one way of evaluating the effectiveness of a course and the basis of the decision on its development and improvement. Ito improve and develop Financial Management in English Institution course it is necessary to analyze student perspective on this subject, from that perspective we can evaluate what need to be improved, added and updated in this course, so the quality of this course can be better.

According to (Cahyati, Rahmijati, Samsudin, \& Firdaus, 2012) Perception is the process by which individuals select, organize and interpret stimuli into a meaningful and coherent picture in the world. Perception is more important than reality because perception can change someones' behavior.Perception is one's ultimate experience of the world and typically involve further processing of sensory input (Ahen, 2009). Individual observe and events occur around them through their sensory receptors such as ayes, ears, nose and etc. (Ahen, 2009) stated that perception is one process where one will form an impression about someone or something. The input gain through one's observation will produce certain judgment or belief which influenced the financial management of an English Institutions.

This research focus to analyze students perception of financial management as a course in English institutions. Expected with this research we can describe how the perception students about financial management in English institutions, so in this research, we can know what the strength, and the weakness of this course.

\section{METHOD}

This research is qualitative descriptive research design. To collect the data, the writer used questionnaires as the instrument of this research. And the population of this research was the final semester of English Education Language students in IKIP Siliwangi in the academic year 2017/2018. This research used quota sampling as the sampling technique. The sample of this research was 51 students from B2, B3 and B regular classes. Percentage calculation used to analyze the data in this research.

\section{RESULTS AND DISCUSSION}

\section{Results}

The result of the questionnaires shows the positive perception of students toward Financial Management in English Institution course. This is seen from the data that presented in the table below. 
Table 1. Students’ Perception Towards Financial Management Course

\begin{tabular}{ccccccc}
\hline Statement & $\begin{array}{c}\text { Strongly } \\
\text { Agree }\end{array}$ & Agree & Disagree & $\begin{array}{c}\text { Strongly } \\
\text { Disagree }\end{array}$ & $\begin{array}{c}\text { Positive } \\
\text { Perspective } \\
\text { Percentage }\end{array}$ & $\begin{array}{c}\text { Negative } \\
\text { Perspective } \\
\text { Percentage }\end{array}$ \\
\hline 1 & 1 & 37 & 12 & 1 & $74.50 \%$ & $25.50 \%$ \\
\hline 2 & 2 & 32 & 16 & 1 & $66.70 \%$ & $33.30 \%$ \\
\hline 3 & 1 & 37 & 12 & 1 & $74.50 \%$ & $25.50 \%$ \\
\hline 4 & 1 & 30 & 19 & 1 & $60.80 \%$ & $39.20 \%$ \\
\hline 5 & 1 & 29 & 21 & 0 & $58.80 \%$ & $41.20 \%$ \\
\hline 6 & 1 & 37 & 9 & 4 & $74.50 \%$ & $25.50 \%$ \\
\hline 7 & 1 & 34 & 14 & 2 & $68.60 \%$ & $31.40 \%$ \\
\hline
\end{tabular}

The first statement concern about students' understanding the objective of Financial Management course show positive response with the percentage of $74.50 \%$ of students have understood the objective of studying Financial Management course, while the other $25.50 \%$ of students don't understand the objective of studying this course.

The second statement is about parts of this course are designed to achieve lecture targets got positive responses $66.70 \%$ of students saw clearly how the parts of this course are well designed to achieve the desired target, while the others $33.30 \%$ of students argue that the parts of this course are not well designed to achieve the target.

The third statement focus on the material in Financial Management course adjusted to the needs of the fields got positive responses $74.50 \%$ of students have perceptions that material in this course has been adapted to the needs of English education institutions, while the rest $25.50 \%$ of students said not sure with this statement.

The fourth statement concern about students' ability to apply the material of this course show positive responses with percentage $60.80 \%$ of students have the ability to apply the material of this course in their daily life and the rest $39.20 \%$ of students won't be able to apply materials that they have learned in the Financial Management in English Institution course according to their capacity and needs.

The fifth statement is about the formation of students' critical thinking in this course have positive response $58.80 \%$ of students have had critical thinking skills after studying this course but the rest $41.20 \%$ of students have not formed their critical thinking skills in this course.

The sixth statement focus on a lot of learning that students get in this course shows positive responses $74.50 \%$ of students have a perspective that they got a lot of learning while studying this course and the rest $25.50 \%$ of students said not sure and the last statement concern about the students' satisfaction to the learning quality of this course got a positive response with the percentage $68.80 \%$ of students satisfied to the quality of learning of this course and while the others $31.40 \%$ of student have a different perspective, they are not satisfied.

\section{Discussion}


There are 7 statements about the subject of Financial Management in English Institution studied by the English education students. And it is intended to measure students' perspective on financial management courses. After analyzed all the statements, we found that $68.35 \%$ of students gave positive perspective toward Financial Management course and the rest $31.65 \%$ of students gave negative perspective.

Each statement has positive responses more than a negative response. In the first statement, $74.50 \%$ students gave positive responses, as the concern about students' understanding the objective of the course this is an indication that most of the students have understood the objective of the lecture the Financial Management course. At the beginning of the lecture, the lecturer has explained well the objective of the course, so the students can understand it. And the rest gave negative responses, that is $25.50 \%$ of students disagree with the first statement, they don't have understood the objective of studying the Financial Management course, this happened because of the material in this course as unusual material for English students, and readiness of students to understand the material. Some students may take longer to understand this course than the other students. The second statement got $66.70 \%$ of students that gave positive responses to this statement,and $33.30 \%$ it means that that the most students agree with that statement. In other words, the parts of the materials in this Financial Management in English Institution course have been well constructed so the students were able to identify the desired targets in this course, but there are students that have negative perspective of that statement, they could not see clearly how the parts of this course assembled to reach the target, this happened because they didn't know the target of this course or the parts of this course was not well assembled.

Same with the first statement, $74.50 \%$ of students gave positive responses to the third statement, this is an indication that $74.50 \%$ students have perceptions that material in this course has been adapted to the needs of English education institutions but $25.50 \%$ students have different perception, in their perception the material of this course has not adapted to the needs of English education institution, this means that there is still some material in this course that has not been adapted to the needs of English educational institutions, and this can be evaluated both for the institution and lecturers that related to this material, to adapt the material to real life needs especially in English education institution so the knowledge that obtained by students can be applied and have usefulness. The fourth statement got $60.80 \%$ as the posititve responses from the students, This indicates that most students take the perception that they have been able to apply materials that they have learned in the Financial Management in English Institution course according to their capacity and needs, for example in managing the daily finance, but the rest students didn't have the ability to apply the material that has learned by students as the impact studying this course, it probably happened because the students didn't understand how to apply the material in real life and the materials were not suitable with their real life financial management.

The statement number 5 show $58.80 \%$ of students gave positive responses. Base on the percentage the most student agree with that statement because most of the material in Financial Management course is a calculation that can train students to think critically about completing a learning activity. But $41.20 \%$ students have a different perspective, they disagree with that statement, the learning activity of this course could not make them thinking critically even though the most material of this course is a calculation. The sixth statement got $74.50 \%$ positive responses from the students. Based on that percentage the most student agrees that they have gained much learning from Financial Management in English Institution course because in this course students have learned the concepts, scope, and application of 
financial management that can be useful in managing the finances of an institution or company including English educational institutions as their educational background. And $25.50 \%$ students disagree with that statement, they haven't gained much learning from this course, and this happened because of many factors, it because of the present while the lecturer, and different concentration that students have. And the last statement also got a positive response more than negative response, that is $68.80 \%$ of students agree with this statement, and the rest of students disagree with this statement. In the other word the percentage indicates that most students are overall satisfied with the quality of the learning that they have received in Financial Management course in English Institution, even though there are $31.40 \%$ students are unsatisfied with the quality of this course, it occurs by many evidence while teaching-learning processes, both the factor from the students or from the lecturer.

All the statement got positive and negative response, it happened by many factors, student's concentration, the unusual material from English major, the presence of students in the lecture, the lecturer ability to deliver the material, the calculation material, and students interest of the courses, all that factors gave influence to the successes of the teaching-learning process in Financial management course.

\section{CONCLUSION}

These results of the study indicated that the students' perception of Financial Management in English Institution course is positive, although there are $31.65 \%$ more students have a negative perspective of this course, in terms of objectives, content, impact, application, and the learning quality of this course. The other words the Financial Management in English Institution course is acceptable even though the material has considerable differences with English education materials. And the negative response can be used as a motivation for the institution to be able to improve the quality of learning in this course and the suitability of the material with the actual financial management of educational institutions, especially in English Institution and minimizes the difference between classroom learning and application in practical work. So the students can be more understand how the application of this course in real life. Therefore, the authorities must design the course curriculum so that students can find synergies between institutions learning and application of that learning in a career.

\section{ACKNOWLEDGMENTS}

Thanks to all related parties including the chairman of English Department IKIP Siliwangi Cimahi, the lecturer supervisor and all respondents who have contributed in writing this research. 
294 Farohah, Setiani, Student's Perception Towards Financial ...

\section{REFERENCES}

Ahen, A. jerry. (2009). Student's Perception Toward English for Self Experiences. University Malaysia Sarawak, 23.

Cahyati, S. S., Rahmijati, C., Samsudin, A., \& Firdaus, N. M. (2012). Analisis Tingkat

Kepuasan Program Studi Pendidikan Bahasa Inggris Terhadap Pelayanan Program Studi

Pendidikan Bahasa Inggris STKIP Siliwangi Bandung. Jurnal STKIP Siliwangi

Bandung, 9, 20.

Howard, J. (2016). Public Financial Management. University of Maryland University College, 5.

Pamungkas, M. y, Kaswan, Sudiyono, \& Hariyudin, A. (2016). Financial Management. 